DOI https://doi.org/10.18551/rjoas.2018-06.59

\title{
FACTORS AFFECTING SUSTAINABILITY OF WATER SUPPLY IN COASTAL COMMUNITY OF TARAKAN ISLAND NORTH KALIMANTAN: AN APPLICATION OF MUTIDIMENSIONAL SCALING METHOD
}

\author{
Azmanajaya Emil \\ Department of Civil Engineering, Balikpapan State Polytechnic, Indonesia \\ Paulus Chaterina Agusta \\ Department of Aquatic Resource Management, Nusa Cendana University, Indonesia \\ *E-mail: emil.azmanajaya@poltekba.ac.id
}

\begin{abstract}
Coastal communities are known to be vulnerable to water needs. They are largely isolated, vulnerable to natural hazards, and climate variability inhibits their ability to obtain adequate water resources to support their lives. Hence, finding a sustainable water supply provision model is a sensible way to address these uncertainties and vulnerabilities. However, achieving sustainable water supply is a challenging issue, as it is influenced by various factors from an environmental, social, economic, technological and institutional perspective. This study assessed the water supply problem by identifying key factors that affect its sustainability. Data were analyzed using the approach of multidimensional scaling. The analysis showed that the multidimensional system of clean water supply on Tarakan is sustainable with 13 sensitive attributes that have an effect on increasing the sustainability index. The attributes are divided into 3 attributes on the environmental dimension, 3 attributes on the economic dimension, 2 attributes on social and cultural dimensions, 3 attributes on infrastructure and technology dimensions, and 2 attributes on legal and institutional dimensions. To improve long-term sustainability status, the scenario that needs to be done to improve the provision of clean water is a prolonged-optimistic scenario by making a thorough improvement of all sensitive attributes.
\end{abstract}

\section{KEY WORDS}

Sustainability, water supply, coastal communities, island.

As one of nature's resources, water on earth is unevenly available. Distribution of water from one place to another place on earth varies according to time and space. Many areas have enough water potential, but it is not uncommon to find areas with very little water potential and often difficulty getting water. Water is an essential need for the survival of living things in everyday life, especially humans (Edyanto, 2011) to support the needs of both agriculture, household, and office. Water serves as engine coolant, raw materials or cleaning or disposal of waste. Coastal communities are known to prone to vulnerability arising from their nature of work (Paulus and Fauzi, 2017). To meet the community's water needs, raw water supply is needed, especially in urban and rural areas (Yasin, et al, 2013). Under Law No. 5 In 1962, Indonesia, providing clean water for urban public or usually run by government-appointed government agencies such as the Regional Water Company (Susanti, 2010).

Geographical factors affect the location and relative distance of water sources and population distribution (Susanti, 2010). Increasing population and its growth rate, the higher the level of utilization of water resources (Susilawaty, et al, 2016). However, many water sources are polluted because of waste generated by economic activities and industries causing water quality that can be directly ingested or public consumption on the wane. It takes a management system and raw water supply to be managed into clean water that can be distributed to the population. The availability of water resources in small islands is particularly vulnerable due to changes in seawater quality. Given the magnitude of the 
function and role of clean water and to anticipate the increasing demand for water in small islands, water supply stems should receive serious attention as it is one of the main sources of clean water resources in small islands (Selintung et al., 2010).

The development of Tarakan as the second gateway of East Kalimantan after the city of Balikpapan in the sailing and aviation traffic caused the attraction to the surrounding community so that the population density increased. Industry, business, and people need clean water for daily use. Tarakan Island, which is surrounded by oceans, produces groundwater and surface water susceptible. The coastal area has strategic significance because it is a transitional area between terrestrial and marine ecosystems, as well as having the potential of natural resources and environmental services are very rich (Paulus et al., 2018). The low coverage of clean water services causes industries and communities to use groundwater and lead to lower groundwater levels and even land subsidence in some places. For that reason, a thorough study of the sustainable small island water supply model is needed.

\section{METHODS OF RESEARCH}

This study was conducted using a survey method through in-depth interviews and observation techniques. Respondents were taken by Purposive Random Sampling with criteria of Respondents Experts who have expertise in accordance with the field under study. Data analysis in this study using Multidimensional Scaling with Approach "Rapid Appraisal Index Sustainability of Land Management that has been modified from Rapfish (Rapid Assessment Technique for Fisheries) developed by Fisheries Center, University of British Columbia (Kavanagh and Pitcher 2001, Fauzi and Anna, 2002).

\section{RESULTS AND DISCUSSION}

Water Supply Sustainability Index. The study of clean water supply conducted in Tarakan Island on the sustainability index of the five dimensions of sustainability, ie environmental, economic, social, infrastructure and technology dimensions, and law and institutions based on the assessment of attributes and expert opinion scores. The result of using Rap-Tarakan analysis shows that the index of the environmental dimension of $31.80 \%$ with an unsustainable status, the index of the economic dimension of $88.24 \%$ with a sustainable status, an index of the social dimension of $57.53 \%$ with less sustainable status, index of dimension infrastructure and technology $20,14 \%$ with less sustainable status, and index of legal-institutional dimension equal to $74,21 \%$ with sustainable enough status. In order for this index value in the future to continue to increase until it reaches a sustainable state, it is necessary to improve the sensitive attributes that influence the value of infrastructure index and technology dimension as well as environmental, economic and social dimension. Attributes that are considered sensitive by experts are based on the conditions of the existing region. Value index of the five dimensions of sustainability of RapTarakan analysis results are presented in Figure 1.

Factors affecting the sustainability index of water supply on Tarakan Island:

Environmental Factor. Factors estimated to affect the sustainability of the environmental dimension consist of (1) water conservation area, (2) frequency of drought occurrence, (3) raw water quality, (4) raw water quantity, (5) rainy \& rainy days, 6 ) development of raw water resources, (7) land use, (8) groundwater levels, and (9) river pollution levels. The leverage analysis used to look at sensitive attributes has an effect on the environmental sustainability index value. Based on the results of leverage analysis, there are three attributes that are sensitive to environmental sustainability index value (1) raw water quantity can be obtained through: rain \& rainy day (2), and development of raw water source (3). Figure 2 provides information on the results of leverage analysis of environmental sustainability dimensions. Attributes that are sensitive to the environmental sustainability index values are (1) the quantity of raw water can be obtained through rain and rainy days 
are the main factors that control the hydrological cycle process in the catchment or watershed area (2), and (3) its development from water source standards.
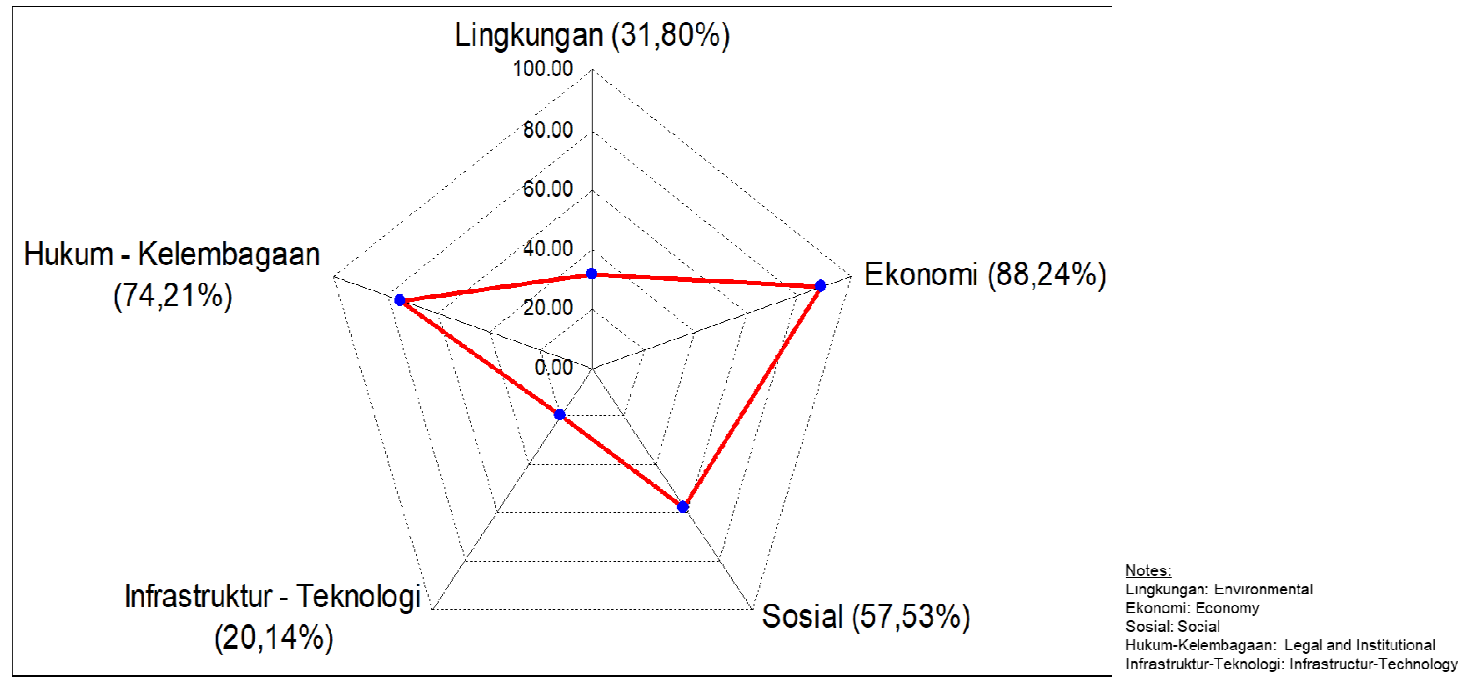

Figure 1 - Kite diagram value of sustainability index on water supply in Tarakan

Rain is water particles with a diameter of $0.5 \mathrm{~mm}$ or more. If it falls to the ground, it is called rain, but if it falls could not reach the ground because it evaporates so the fall is called Virga. Rain can also be defined by condensation vapor and falls in a series of hydrological processes. Rain is a form of vapor deposition that comes from clouds in the atmosphere. Other forms of rainfall are snow and ice. For the occurrence of rain required condensation points, ammonia, dust and sulfuric acid. This condensation dots have properties that can remove moisture from the air. Rainfall units are always expressed in millimeters or inches but for Indonesia, the unit of rainfall used is in millimeters $(\mathrm{mm})$. Rainfall is the height of the rainwater collected in a flat, unstable, not pervasive, and non-flowing place. Rainfall of 1 (one) millimeter means in the area of one square meter in a flat place collected water as high as one millimeter or contain water as much as one liter. Rain intensity is the number of rainfall units for a certain period of time. Other factors that lead to low rainfall or prolonged drought is the impact of climate change on small islands such as emerging global natural phenomenon EI Nino with consequent impact on the global climate fluctuations or variability in the presence of drought and floods in other places (Paulus and Sobang, 2017). The average Tarakan Island rainfall in 2008 reached $330.8 \mathrm{~mm}$ per year with the highest average rainfall occurring in January of $443.6 \mathrm{~mm}$ and the lowest average rainfall of $206.6 \mathrm{~mm}$ occurred in October (BPS Tarakan, 2009).

In order to improve the sustainability status of Tarakan Island, remedial efforts are not only done to sensitive attributes that affect the environmental sustainability index, but other insensitive attributes based on leverage analysis also need serious attention to be addressed. Efforts that need to be made to maintain or enhance attributes that have a positive impact on increasing the dimension of environmental sustainability of the region and can minimize attributes that negatively impact on the sustainability of diminishing regional environmental dimensions. Attributes that need to be maintained or enhanced include: (1) water conservation area, (2) groundwater level and (3) surface water quality, while attributes that need to be suppressed so as not to negatively impact the decreasing of sustainability status of the area are land use for water quality, and drought frequency using dam construction, embankment, flood retention and drainage for water resources management, and making absorption wells.

Economic Factor. Factors affecting sustainability in the economic dimension consist of seven attributes, namely (1) the PDAM's (local water utility company) profit level, (2) the water cost of the PDAM, (3) the percentage of the poor, (4) price discrimination between and (5) willingness to pay, (6) contribution of utilization of water resources for PDRB (gross 
regional revenue), and (7) availability of fund for clean water development. Based on the results of leverage analysis, the three attributes that are sensitive to the economic sustainability index value are (1) the level of PDAM's profit, (2) the water costs of the PDAM, and (3) willingness to pay (willingness to pay in the use of water resources).

The attributes that are sensitive to the value of economic sustainability index dimension are (1) the level of PDAM's profit, (2) water cost of PDAM and (3) willingness to pay. Water cost is the price in rupiah that PDAM customers must pay for each use of cubic meters of clean water supplied by PDAM (Regulation of Ministry of Home Affairs No. 2 Year 1998). The amount of cost is a mutual agreement between the provider of clean water service (PDAM) with the users of clean water service (customer), while the role of government in carrying out its functions as the regulator of the water resources sector should in determining the policy in the field of drinking water pay determination deliberate considerations of the willingness and willingness to pay on the one hand and the survival of the enterprise on the other. To find out the ability and willingness of paying, it is necessary to analyze the affordability of consumers' purchasing power in paying cost which includes willingness to pay analysis and ability to pay analysis against the prevailing cost.

Low levels of economic constraints for the sustainability of the water supply system. One indicator of the sustainability of the system is the level of customer satisfaction. Sustainability can be ensured by good management and supported by community participation, either in the form of water usage smoothness payment or direct involvement in every stage of the water services. Management and community involvement are both pushing the reliability of the water supply system, which in turn increases the level of satisfaction of the people.

Social Factor. Factors affecting sustainability in the social dimension consist of seven attributes, namely (1) the level of formal education of the community, (2) understanding and awareness of the community towards the conservation of water resources, (3) community empowerment in clean water utilization activities, (4) ) the level of public complaints against PDAM customers, (5) the level of community dependence on clean water, (6) the role of indigenous peoples in water utilization activities, and (7) water source conflict. The results of leverage analysis reveal two attributes that are sensitive to the value of the social sustainability index, namely (1) the level of customer complaints to the PDAM and (2) the level of community dependence on clean water. Both these sensitive attributes have a close relationship in order to meet the need for clean water, the community depends heavily on clean water in everyday life, but if the clean water obtained does not match the quantity and quality required will cause problems and usually a complaint.

Water is an important component of the environment to life. Life on earth can not be separated from the water requirement. Water is a major requirement for the process of life on earth, so there is no life if there is no water on earth. However, water can be disastrous when it is not available under appropriate conditions, both quality and quantity. Clean water is highly coveted by humans, both for daily life, for industrial purposes, for agricultural purposes and so forth. Water today is a matter of concern, this is due to the difficulty of getting clean water in accordance with certain standards, water becomes scarce and expensive. Contamination of water by various kinds of waste from human activities, whether waste from household activities, waste from industrial activities and other activities, as well as human dependence on water increases with population growth. In addition to water quality degradation due to pollution of water sources, insufficient amount of clean water that can be used by the community can also cause problems for public health such as the incidence of diseases caused by water use such as diarrhea, scabies and trachoma. To improve the sustainability status of social factors, it is necessary to pay attention to the public's complaints about the dependence of clean water worth consuming (quality) and the quantity of public demand for clean water (quantity).

Customer complaints to PDAMs are a matter of customer satisfaction. Customer satisfaction or also called Total Customer Satisfaction according to Barkelay and Saylor (1994) is the focus of Customer-Driven Project Management (CDPM) even in the process stating that customer satisfaction is quality. So is the short definition of quality expressed by 
Juran (1993) that quality is customer satisfaction. According to Kotler cited Tjiptono (1996) that customer satisfaction is the level of one's feelings after comparing the perceived performance (or results) with hope. Thus, the level of satisfaction is a function of the difference between perceived performance and expectations. Quality includes all the elements necessary to meet customer goals, both internal and external, and includes every item in product quality, service quality, performance, availability, durability, aesthetics, reliability, maintenance, logistics, support, customer service, training, delivery, billing, shipping, repair, marketing, warranty, and life cycle costs.

Through communication, both between customers and with suppliers will make expectations for customers to the quality of products to be purchased. Understanding customer expectations by suppliers is an input to improve and improve product quality, both goods, and services. Customers will compare with other service products. When his expectations are met, it will make him a loyal customer, satisfied with the product or service he bought. Conversely, when not satisfied, the supplier will be abandoned by the customer. Key customer decisions relate to satisfaction with a valuation of goods and services. The customer satisfaction framework lies in the supplier's ability to understand customer needs, wants and expectations so that the delivery of products, both goods, and services by suppliers in accordance with customer expectations. In addition to the factors mentioned above, the time dimension also affects the customer perception responses to product quality, both goods, and services.

The word quality contains many definitions and meanings because different people will interpret it differently, such as conformity with requirements or demands, suitability for the use of continuous improvement, free of defects or defects, customer needs fulfillment, doing all the happiness. In the perspective of TQM (Total Quality Management) the quality is viewed more broadly, which is not only an aspect of the emphasized result, but also includes the process, the environment and the human. This is clearly evident in the definition formulated by Goeth and Davis citing Tjiptono (2000) that quality is a dynamic condition associated with products, services, people, processes, and environments that meet or exceed expectations. In contrast, according to Lukman (1999) the definition of quality varies from controversial to more strategic. Conventional quality definitions usually describe the immediate characteristics of a product, such as: 1) performance; 2) reliability; 3) easy to use; and 4) aesthetics, and so on. Therefore, quality in principle is to keep the customer's promise that the parties served are fulfilled and disclosed. Quality has a very close relationship with customer satisfaction, ie quality gives impetus to customers to undergo a strong relationship with the company. In the long run term, this relationship allows companies to understand carefully the expectations of customers and their needs. Thus, the company can increase customer satisfaction, which in turn customer satisfaction can create customer loyalty or loyalty to companies that provide satisfactory quality.

Infrastructure and Technology Factors. Factors affecting infrastructure sustainability and technological dimensions consist of six attributes, namely (1) PDAM service level, (2) wastewater infrastructure, (3) drainage conditions in residential areas, (4) pipeline network condition, (5) water supply condition of IPAM (drinking water treatment plant), and (6) availability of electricity service for water treatment. Leverage analysis yields three attributes that are sensitive to the value of infrastructure and technology sustainability indexes (1) service level of PDAM (water supply) and (2) IPAM condition of PDAM, therefore (3) availability of electricity service for water treatment to support clean water service for Tarakan Island community.

The service level of PDAM in Tarakan is still low, in some cases the clean water that occurs in the field is still water that is not clean. One example, water from the PDAM if it flowed into the bath or shelter after a few hours then the water becomes yellow. According to Lukman (1999: 11) service are activities that are not clear, but provide customer satisfaction and or industrial users and are not bound on the sale of a product or service others. It further said that service is a sequence of activities which occurs in direct interaction with people or machines physically and provide customer satisfaction. 
Government as a bureaucratic institution has a function to provide services to the community. In contrast, the community as the party mandating the government has the right to service. Therefore, the demand for public services gave birth to a study, namely service how to provide the best service and improve the quality of public services. Apparatus as servants should understand the service variables as contained in the agenda of public sector service prime services as LAN hotspots cited by Lukman (1999). The variables are as follows: (1) Government in charge of serving, (2) Communities served by the government, (3) Policies on which public services are based, (4) sophisticated equipment or service targets, (5) Resources available for (7) Management and leadership and community service organizations, and (8) Behaviors involved in service and community, each describing the function. These eight variables indicate that the importance of today's quality of community service cannot be ignored, even to be tailored to the demands of globalization.

Legal and Institutional Factors. Factors affecting sustainability in the legal and institutional dimension consist of five attributes, namely (1) presence of a water quality monitoring center, (2) presence of social institutions, (3) availability of water management regulations (4) availability of customary law, and (5) cooperation among stakeholders. The results of leverage analysis reveal two sensitive attributes namely (1) the existence of social institutions, and (2) availability of water management legislation. Targeted use of clean water for social purposes. In accordance with the Joint Decree of the Minister of Home Affairs and Minister of Public Works no. 4 Year 1984, PDAM as the clean water sector (SAB) economic actors provide services and regulate public benefits. This implies that PDAMs should be able to formulate objective social interests, tailored to their internal circumstances, and select the area of operation that should be. The second operational step of this objective has been done through the allocation of water to the public hydrant connection terminals. Other operational measures, though less directly correlated with the strategy of increasing the population of service is a clean water supply to the water crisis regions or other disasters.

Strategies for the development of the SAB is motivated by the fact that SAB institutions associated with the taps with other external parties and not run optimally in providing water services. This indirectly puts SAB itself (status quo) in the development of the SAB, the implication is that efforts to find a new institutional structure that is believed to be more effective and efficient can not be realized, and always can cause leakage factor (externalities) which harm either party. With this strategy all the stakeholders expected to look objectively the factors or variables that affect the level of access to clean water and found the agent formulation SAB management more efficient and sustainable.

SAB's institutional development strategy has three objectives. First, build community participation in SAB development. The relationship between PDAMs as producers and customers as consumers is not sufficient in exploring potential benefits in the development of SAB. Community participation must touch the scientific and academic side so as to identify the characteristics of clean water from all points of view and involve professional sectors in their fields. This first target operational step is prioritized to build communication networks among stakeholders involved in SAB development, especially from governments, the private sector, consumers, non-government and research groups. Networking is not enough to facilitate problem solving, but also to run high-quality, rich-incentive communication for the invention of new technologies. The network at the international level that deals with water resources and includes SAB is global water. The next step can be to conduct research on the behavior of clean water consumption and the factors that influence it. Various studies (World Bank 1993, Jordan and Elnagheeb 1993) show that communities can demonstrate their willingness to pay response to new pipeline connections as well as improved water services and water quality.

Second, the goal of developing an efficient and sustainable SAB economic institution. The existence of PDAM as an economic institution of water actors is fully related to the municipal or district government. This situation is in many ways contrary to the economic scale and efficiency of the allocation of raw water sources so that the potential benefits do not materialize as a result of the current institutional structure. The recommended operational step is to formulate the institutional relationship between PDAMs with government and the 
private sector in ensuring the efficiency of raw water allocation and customer service operations. Furthermore, the most profitable management options can be arranged, for example: PDAM Surabaya, Gresik, and Sidoarjo have the opportunity to gain relatively large social benefits if they are in a single management. The same can be done between urban and district areas, even mergers in one ex-residency. SAB in Malaysia has only 18 management institutions (Malaysia Water Supply Development, 2001), much more efficient than 307 PDAMs in Indonesia, or 37 PDAMs in East Java. The next operational step is to establish institutional mechanisms that support the PDAM's authority and independence to improve functionally by LGs and technically by the relevant technical directorates. The objectives of developing sustainable economic institutions can be implemented by incorporating environmental variables in PDAM performance evaluation standards, such as applying ISO 9000 or environmental auditing. Thus, the entire production process, the distribution of clean water and the surrounding environment is protected by high quality standards.

Third, develop the legal institutions of SAB. SAB's legal instruments may not be exclusive but may be inherent in applicable law. Incentives in the form of an award should be given to the stakeholders who have contributed to the development or support of the development of the water sector and sanctions imposed on those who violate or counterproductive to efforts to improve water services, so that the availability of water management law.

Multidimensional Index. Result from multidimensional analysis of Rapuh Tarakan for water supply based on existing condition, sustainability index value is $52,38 \%$ included in continuous status. This value is derived based on the assessment of factors on 34 attributes of the five dimensions of sustainability: environment, economy, social, infrastructure and technology, and legal and institutional dimensions. Multidimensional analysis results with Rap-Tarakan for water supply system can be seen in Figure 2.

The sensitive attribute contributes to the value of the multidimensional sustainability index based on the leverage analysis of each dimension of 13 attributes. These attributes need to be upgraded in the future to improve the sustainability status Tarakan Island's water supply system. The intended increase is to increase the capacity of attributes that have a positive impact on increasing sustainability index values and instead minimize attributes that may have a negative impact or lower the value of the region's sustainability index.

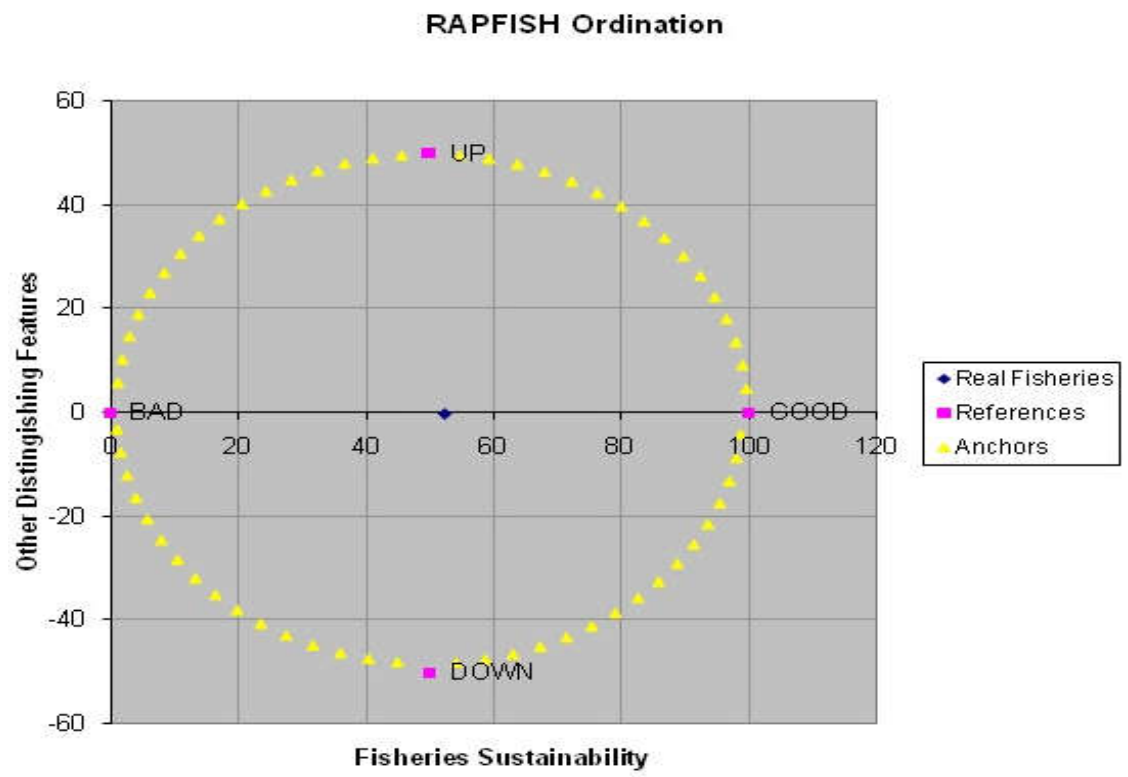

Figure 2 - Multidimensional Sustainability of Water Supply Index in Tarakan Island

Monte Carlo analysis shows that the index value of a clean water supply on the island of Tarakan at a rate of $95 \%$ shows the results did not change much with the results of the 
analysis of multidimensional scaling (MDS). This means that errors in the analysis can be minimized both in terms of the assessment of each attribute, the variations in the assessment due to relatively small disputes, and the data analysis process performed repeatedly stable, and errors in the input data and lost data can be avoided. The differences in the sustainability index values of MDS and Monte Carlo analysis are presented in Table 1.

Table 1 - Differences value of the index Sustainability Monte Carlo Analysis with the Rap-Tarakan

\begin{tabular}{llll}
\hline \multirow{2}{*}{ Sustainability Dimensions } & \multicolumn{2}{l}{ Value of the Sustainability Index (\%) } & Difference \\
\cline { 2 - 4 } & MDS & Monte Carlo & 0.95 \\
\hline Environmental & 31,80 & 32,75 & 2.75 \\
Economy & 88,24 & 85,67 & 0.32 \\
Social & 57,53 & 57,21 & 2.15 \\
Infrastructure and Technology & 20,14 & 22.29 & 0.81 \\
Legal and Institutional & 74,21 & 73,40 & 0.20 \\
Multidimensional & 52,38 & 52.18 & \\
\hline
\end{tabular}

Rap-Tarakan results of the analysis showed that all of the attributes studied for sustainability status Tarakan Island for water supply accurate enough to provide better results and be more responsible. It can be seen from the voltage value of only about 13 to $15 \%$ and the coefficient of determination (R2) obtained ranged between 0.92 and 0.95 . This is consistent with Fisheries (1999), which states that the results of the analysis are adequate if the stress value is less than $0.25(25 \%)$ and the value of the coefficient of determination (R2) approaches 1.0. Stress and the coefficient of determination (R2) are presented in Table 2.

Table 2 - Value of Stress \& Determination Coefficient (R2) Rap-Tarakan

\begin{tabular}{|c|c|c|c|c|c|c|}
\hline \multirow{2}{*}{ Parameters } & \multicolumn{6}{|c|}{ Sustainability Dimensions } \\
\hline & A & $\mathrm{B}$ & $\mathrm{C}$ & $\mathrm{D}$ & $\mathrm{E}$ & $\mathrm{F}$ \\
\hline Stress & 0.13 & 0.13 & 0.15 & 0.14 & 0.15 & 0.13 \\
\hline $\mathrm{R}^{2}$ & 0.95 & 0.95 & 0.92 & 0.95 & 0.94 & 0.95 \\
\hline Iteration & 2 & 2 & 3 & 2 & 2 & 2 \\
\hline
\end{tabular}

Description: $A=$ Environmental, $B=$ Economy dimension, $C=$ Social, $D=$ Infrastructure-Technology, $E=$ LegalInstitutional, and $F=$ Multidimensional.

\section{CONCLUSION}

Based on the provision of clean water on Tarakan Island to existing conditions in the study sites, the sustainable economic dimension and legal and socio-institutional dimensions are sustainable enough to be less sustainable, while the environmental dimensions and infrastructure-technologies are unsustainable. Water supply systems Tarakan have 13 sensitive attributes that need to be corrected to improve the sustainability index. These attributes are divided into 3 attributes of environmental dimensions, 3 attributes of the economic dimension, 2 attributes of social and cultural dimensions, 3 tech-infrastructure attributes, and 2 attributes of legal-institutional dimensions. The strategy of upgrading the clean water supply system's sustainability status on Tarakan Island in the long run in the future, so the scenario that needs to be done is an optimistic progressive by completely combating all the sensitive attributes, at least 3 attributes of key factors of environmental dimensions and infrastructure-technology, namely: (1) the amount of raw water in the catchment and watershed, (2) development of standard water source, and (3) the PDAM water supply service.

\section{REFERENCES}

1. Barkley, Bruce T and James H Saylor. 1994. Customer Driven Project Management, A New Paradigm in Total Quolity Implementation Singapore.

2. BPS Kota Tarakan. 2009. Kota Tarakan dalam Angka 2009. Tarakan. East Kalimantan. 
3. Edyanto, C. H. 2011. Penelitian Sumber Air Bersih Bawah Tanah Di Pulau Flores. Jurnal Teknologi Lingkungan, 9(2)

4. Fauzi, A. dan S. Anna. 2002. Evaluasi status keberlanjutan pembangunan perikanan: Aplikasi pendekatan Rapfish (Studi kasus perairan pesisir DKI Jakarta). Jurnal Pesisir dan Lautan, 4(3): 43 -55.

5. Fisheries. 1999. Rapfish Software for Excel. Fisheries Center Research Reports.

6. Hardjomidjojo, H. 2006. Panduan Analisis Prospektif. Materi Kuliah Program Studi Pengeloaan Sumberdaya Alam dan Lingkungan. Sekolah Pascasarjana. IPB. Bogor. 23hal.

7. Jordan, J. L. and A. H. Elnagheeb. 1993. Willingness to pay for improvements in drinking water quality. Water Resources Research 29(2): 237-245.

8. Juran J.M. dan Griya, F.M. 1993. Quality Planning and Analysis. 3 ED. Singapore: MicGraw Hill.Inc.

9. Kavanagh P. 2001. Rapid Appraisal of Fisheries (Rapfish) Project. Rapfish Software Description (for Microsoft Excel). Vancouver: University of British Colombia, Fisheries Center. Canada. 10(2): 352-370.

10. Lukman, S. 1999. "Visi, Misi, dan Manajemen Pelayanan Prima". Makalah dalam Lokakarya Strategi Pengembangan Pelayanan Umum di Lingkungan Pemerintah Daerah, Cisarua, Bogor.

11. Malaysia Water Supply Development. 2001. http:///www.mywatersupply.org [28 September 2001].

12. Paulus, Chaterina Agusta, Y.U.L Sobang, Marthen R. Pellokila and Emil Azmanajaya. (2018). The Sustainability Development Status of Pigs Livestock on Traditional Fishery Household In Nembrala Village of Rote Ndao Island. Russian Journal of Agriculture Socio-Economice Sciences. RJOAS, 4(76), April 2018. DOI https://doi.org/10.18551/rjoas.2018-04.34.

13. Paulus, Chaterina A. dan Yohanis U.L. Sobang. (2017). Alternative Livelihood" Strategy To Improve Social Resilience of Fisher Households: A Case Study in Nembrala Village of Rote Ndao Regency. ECSOFiM: Journal of Economic and Social of Fisheries and Marine. 2017. 05 (01): 13-21. DOI: http://dx.doi.org/10.21776/ub.ecsofim.2017.005.01.02.

14. Paulus, C., \& Fauzi, A. (2017). Factors Affecting Sustainability of alternatives livelihood in coastal community of Nembrala East Nusa Tenggara: An Application of MICMAC Method. Jurnal Ekonomi Pembangunan: Kajian Masalah Ekonomi dan Pembangunan, 18(2), 34-41. doi: https://doi.org/10.23917/jep.v18i2.4397.

15. Pitcher and Priekshot. 2001. Rapfish: A Rapid Appraisal Technique to Evaluate The Sustainability Status of Fisheries Research 49(3): 225-270.

16. Selintung, M., Zubair, A., dan Rakhmani, D. 2010. Studi Sistem Penyediaan Air Bersih Di Pulau Barrang Lompo Kecamatan Ujung Tanah Kota Makassar.

17. Susanti, R. 2010. Pemetaan Persoalan Sistem Penyediaan Air Bersih Untuk Meningkatkan Kualitas Sistem Penyediaan Air Bersih di Kota Sawahlunto. Journal of Regional and City Planning, 21(2), 111-128.

18. Susilawaty, A., Amansyah, M., dan Nildawati, N. 2016. Kerentanan Ketersediaan Air Bersih di Daerah Pesisir dan Pulau-Pulau Kecil Sulawesi Selatan Indonesia. Al-Sihah: The Public Health Science Journal, 8(2).

19. Tjiptono Fandy. 1996. Manajemen Jasa. Yogyakarta

20. Tjiptono Fandy. 2000. Prinsip- Prinsip Total Quality Service. Yogyakarta

21. World Bank. 1993. The demand for water in rural areas: determinants and policy implications. World Bank Research Observer. 8(1): 47-70.

22. Yassin, M. O., Kawet, L., Halim, F., dan Jasin, M. I. 2013. Pengembangan Sistem Penyediaan Air Bersih Untuk Zona Pelayanan IPA Pilolodaa Kota Gorontalo. Jurnal Sipil Statik, 1(12). 